\author{
Vlasta ONDREJKA HARBULÁKOVÁ ${ }^{1}$ \\ Adriana EŠTOKOVÁ ${ }^{2}$ \\ Nadežda ŠTEVULOVÁ ${ }^{3}$ \\ Katarina FORAIOVÁ ${ }^{4}$
}

\title{
METHODS FOR EVALUATION OF SEWER PIPES MATERIAL DETERIORATION
}

\begin{abstract}
Most of sewer pipelines are concrete that has been either cast in place of precast. Sulphide corrosion occurs above the sewage surface while low $\mathrm{pH}$ sewage will cause corrosion below waterline. It can be very difficult to distinguish between purely chemical and biogenic concrete deterioration as both processes may depend on acid attack. It is very important to review and define appropriate test methods to asses performance of cement - based materials in environments of sewer system and which can be used to characterize and rate relative performance, as well as to inform long term prediction. The paper is aimed at the presentation of the selected methods used for testing the concrete composites for the resistance against sulphate attack.
\end{abstract}

Keywords: sewer pipes, deterioration, investigation of corrosion, concrete

\section{Introduction}

Concrete corrosion has an enormous economic impact world-wide when the replacement or repair of municipal sewer system is required [1]. Microbiologically influenced corrosion (MIC) of material is common in aquatic environments [2]. N. De Biele published in [3] that factors influencing the rate of and extent of attack include for example strength of the acid in the attacking solution, $\mathrm{pH}$ and

\footnotetext{
${ }^{1}$ Corresponding author: Vlasta Ondrejka Harbulakova, Institute of Environmental Engineering, Vysokoskolska 4, 04200 Kosice, Slovakia, +421 55602 4269, vlasta.harbulakova@tuke.sk

2 Adriana Estokova, Institute of Environmental Engineering, Vysokoskolska 4, 04200 Kosice, Slovakia, +42155602 4265, adriana.estokovaa@tuke.sk

3 Nadezda Stevulova, Institute of Environmental Engineering, Vysokoskolska 4, 04200 Kosice, Slovakia, +42155602 4269, nadezda.stevulova@tuke.sk

${ }^{4}$ Katarina Foraiova, Eastern Slovakia Water Supply Company, Komenskeho 50, 04201 Kosice, Slovakia,vlasta.harbulakova@tuke.sk
} 
concentration of the attacking solution, physical state of the attacking medium, temperature or alternate wetting and drying.

The choice of the degradation measure may lead to different conclusions regarding to the relative performance of concrete types. For instance tests De Biele et al in [4] used both the mass loss and thickness change as parameter to judge degradation. Bertron et al. [5] investigated the effect of $\mathrm{pH}$ on mineralogical and chemical modification in the cement-based matrix of ordinary Portland cement and slag cement pastes submitted to organic acids mixes. They wanted to assess if use of an aggressive solution of $\mathrm{pH}=4$ to accelerate alteration kinetics, would not change the degradation mechanisms in comparison to a solution with $\mathrm{pH}$ of 6, which is more realistic in the case of liquid manure attack.

Because of a lack of standardised methods, different test methods have been used, and various parameters have been modified to evaluate the resistance of the materials. The research done of sulphuric acid corrosion of concrete can roughly be divided in three groups: chemical tests, microbial simulation tests, and exposure tests in situ [6].

Maltais et al. [7] used microprobe analysis together with SEM and XRD analyses to establish chemical composition of phases after degradation of Portland cement systems in deionised water and sodium sulphate solutions. Waste form degradation was assessed by measurement of $\mathrm{Ca}$ concentrations in leachates ad by scanning electron microscopy (SEM) combined with energy dispersive $\mathrm{X}$-ray (EDX) analysis of waste form samples. Ca analysis was performed by atomic absorption spectrophotometry [8]. The atomic force microscope (AFM) has been used in the study of the surface topology of a variety of materials [9] and [10]. Beech et al. [11] reported an AFM study of sulphate-reducing bacteria (SRB) biofilm corrosion and visualized the submicrometer features of marine SRB cells on mica.

Electrochemical methods, including direct current methods, alternating current impedance spectroscopy, and electrochemical noise measurement, are also commonly used to study MIC. These methods, however, often assume uniform chemical and electrochemical conditions [12] and [13].

The paper is aimed at the presentation of the selected methods used for testing the concrete composites for the resistance against sulphate attack.

\section{Chemical analysis of wastewater}

Sewer system of the Kosice city was chosen for the testing of microbially induced corrosion processes. Concrete samples were placed to the sewage for 6 , 12 and 18 months and after these periods were evaluated by different methods.

Knowledge of chemical as well as microbial composition of wastewater which is in permanent contact with the wall of the sewer system (with the concrete) is very important. On the one hand, water can reacts with the material deleteriously, on the other hand microogranisms existing in the wastewater cause 
also many aggressive processes towards the sewer and it could leads to cracks and failures of the construction.

Tables 1 and 2 show the results of laboratory analysis of wastewater in the study point where the tested samples were placed. The results in Table 1 response to the period without rain and in Table 2 to the period with intensive rain occurrence. Sampling was done around the same time (in the morning, during working day) in the spring.

Tab. 1: Results of laboratory analysis of wastewater during the dry period without precipitation

\begin{tabular}{|l|l|l|}
\hline indicator & unit & value \\
\hline $\mathrm{SO}_{4}{ }^{2-}$ & $\mathrm{mg} / \mathrm{l}$ & 57.90 \\
\hline $\mathrm{pH}$ & - & 7.70 \\
\hline $\mathrm{COD}_{\mathrm{Cr}}$ & $\mathrm{mg} / \mathrm{l}$ & 16.0 \\
\hline $\mathrm{NL}_{105}$ & $\mathrm{mg} / \mathrm{l}$ & 11.0 \\
\hline $\mathrm{RL}_{105}$ & $\mathrm{mg} / \mathrm{l}$ & 485.0 \\
\hline $\mathrm{P}_{\text {tot }}$ & $\mathrm{mg} / \mathrm{l}$ & 0.787 \\
\hline Ammonia ions & $\mathrm{mg} / \mathrm{l}$ & 10.90 \\
\hline Clostridium spp. & $\mathrm{KTJ} / 100 \mathrm{ml}$ & 100 \\
\hline $\mathrm{N}^{-N_{4}}{ }_{4}^{+}$ & $\mathrm{mg} / \mathrm{l}$ & 8.464 \\
\hline
\end{tabular}

Tab. 2: Results of laboratory analysis of wastewater during the period with precipitation

\begin{tabular}{|l|l|l|}
\hline indicator & unit & value \\
\hline $\mathrm{SO}_{4}{ }^{2-}$ & $\mathrm{mg} / \mathrm{l}$ & not determined \\
\hline $\mathrm{pH}$ & - & 7.59 \\
\hline $\mathrm{COD}_{\mathrm{Cr}}$ & $\mathrm{mg} / \mathrm{l}$ & 289.0 \\
\hline $\mathrm{NL}_{105}$ & $\mathrm{mg} / \mathrm{l}$ & 182.0 \\
\hline $\mathrm{RL}_{105}$ & $\mathrm{mg} / \mathrm{l}$ & 592.0 \\
\hline $\mathrm{P}_{\text {tot }}$ & $\mathrm{mg} / \mathrm{l}$ & 4.03 \\
\hline Ammonia ions & $\mathrm{mg} / \mathrm{l}$ & 19.6 \\
\hline Clostridium spp. & $\mathrm{KTJ} / 100 \mathrm{ml}$ & not determined \\
\hline E.coli & $\mathrm{KTJ} / 100 \mathrm{ml}$ & 15000 \\
\hline $\mathrm{N}^{-N_{4}}{ }_{4}{ }^{+}$ & $\mathrm{mg} / \mathrm{l}$ & not determined \\
\hline
\end{tabular}

It is clearly visible influence of rain as dilution factor on the chemical and microbiological composition of wastewater. These findings are also confirmed in [19].

Results of laboratory analysis of the monitored point show that in the present sewer collectors are sulfur and sulphate-reducing bacteria - Clostridia spp., sulphate-reducing and E. coli, while their quantity is affected by dilution of rainwater. 


\section{Classification of test methods}

In general, testing methods can be classified in different way, some of them (which were used by our research team) are listed below:

\subsection{Mechanical testing methods}

Concrete in service is subjected to a variety of conditions of exposure, such as frequency of drying and wetting cycles, different temperatures, superficial carbonation, drying shrinkage and sulphate and microbial attack. All the conditions will affect the mode of attack. Therefore, it is difficult to exact duplicate the field attack condition in the laboratory. Though the site corrosion test can better simulate the actual corrosion process, it always took much time to fulfill the corrosion.

Compressive strength of concrete is a parameter used for the evaluation of the durability or deterioration when testing big specimens. Decrease in concrete compressive strength, comparing with the original one, can indicate the deterioration process proceeding.

Compressive strength values were measured at the concrete cubes $(150 \mathrm{~mm}$ x $150 \mathrm{~mm}$ x $150 \mathrm{~mm}$ ) after 28 days of hardening (reference sample) and after the 6,12 , and 18-month exposition to waste water in sewerage. In the Fig. 1 the placing of the concrete samples into the sewer system for different time period is shown. This DN 600 sewer collector is an united sewer system for conduction rain and wastewater.

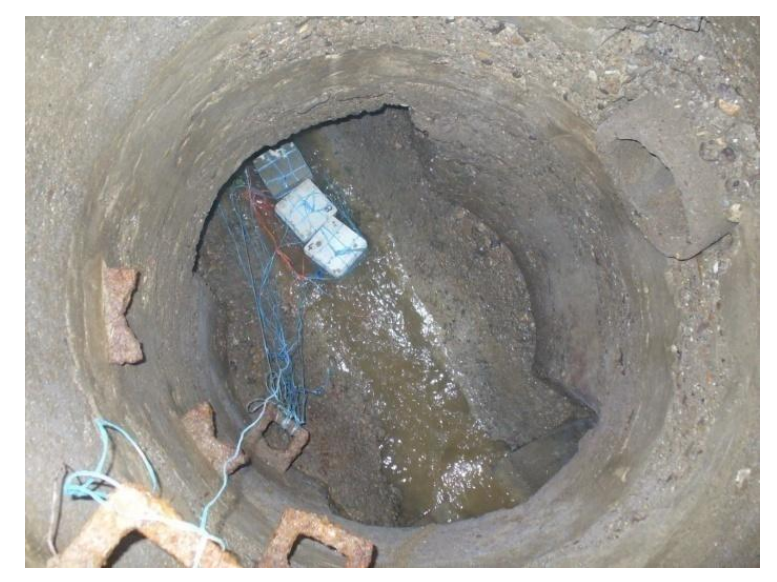

Fig. 1 Concrete samples placed into the sewer system of Kosice city

All samples were evaluated according to the STN EN 206. As it was published in our previous work [14], after the value of the compressive strength reached the top point (maximum hydratation) the concrete led to disintegration. 
18 month exposition in wastewater seems to be enough for the concrete deterioration process starting resulted in compressive strength decrease by $30.6 \%$ when compared to the 12 months exposition.

\subsection{Psysico - chemical methods}

\subsubsection{X-Ray fluorescence analysis XRF}

Biocorrossion of concrete is often manifested by leaching the main components such as calcium and silicon compounds from the cement matrix. X-Ray fluorescence analysis XRF is an appropriate method for testing the changes in chemical composition of concrete samples.

Chemical composition of concrete samples was investigated by X-ray fluorescence analysis (XRF) using SPECTRO iQ II (Ametek, Germany) with SDD silicon drift detector with resolution of $145 \mathrm{eV}$ at 10000 pulses. This method was used for investigation of the chemical composition of the concrete samples before and after the experiment. It was confirmed that the ratios of $\mathrm{Si} / \mathrm{Ca}, \mathrm{Si} / \mathrm{Al}$ and $\mathrm{Si} / \mathrm{Fe}$ measured in concrete samples have been changed during the various time of concrete samples exposition ( $0,6,12$ and 18 months) to the waste water and it was published in [15].

\subsubsection{SEM/EDX analysis}

Scanning electron microscopy (SEM) can be used for the morphological analysis of corroded concrete samples surface. As reported in [16, 17], plenty of disruption and missing aggregates of concrete were observed after the biocorrosion experiment on the concrete surface. The presence of gypsum $\left(\mathrm{CaSO}_{4} \cdot 2 \mathrm{H}_{2} \mathrm{O}\right)$ and ettringite $\left(3 \mathrm{CaO} \cdot \mathrm{Al}_{2} \mathrm{O}_{3} \cdot 3 \mathrm{CaSO}_{4} \cdot 32 \mathrm{H}_{2} \mathrm{O}\right)$ as surface precipitate products was confirmed on the concrete sample surface by electron microscopy and detected by EDX analysis as it is illustrated in Figures 2

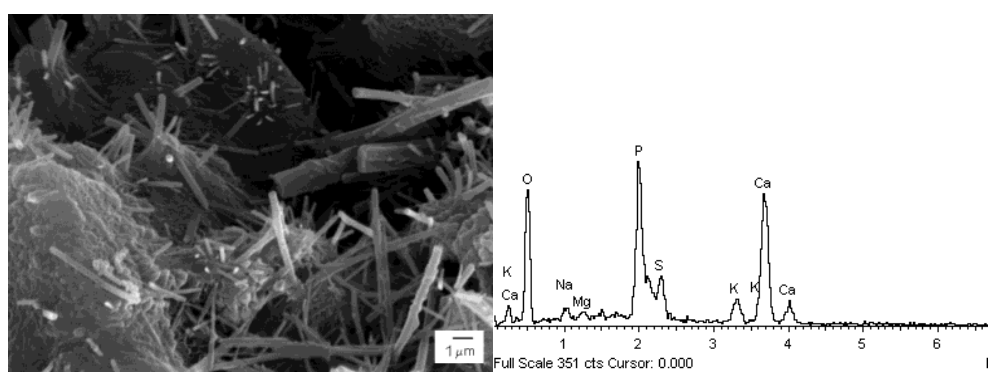

Fig. 2 SEM micrograph of ettringite precipitates 


\subsection{3. pH values changes}

Changes in $\mathrm{pH}$ values of leachates, in which the analysed concrete samples under laboratory conditions have been immersed, may confirm the releasing of alkali calcium and silicon compounds.

Our previous results [18] confirmed that $\mathrm{pH}$ values of all concrete leachates had been shifted into the alkali region up to 9 . The increase in $\mathrm{pH}$ has been measured to be higher in presence of sulphur-oxidising bacteria when comparing to chemical sulphate attack. The presence of calcium and silicon ions in leachates was found out.

\subsection{Other methods}

\subsubsection{Camera monitoring}

Camera Monitoring of sewer system of Kosice city was examined by the operator studied public sewer - by VVS, a.s. Kosice (Eastern Slovakia Water Supply Company) under inspection monitoring program of sewer pipes, which is part of an operational monitoring under Ministry of Environment Decree No. $315 / 2004$ which establishes the scope and frequency of sampling and the scope and requirements for carrying out analyzes of wastewater.

Before the start of camera survey it is necessary to make preparations for the survey, which includes:

- gaining of maps that include topography, plotting positions, including planimetric existing sewer manholes with their name, length, shape and dimensions of individual sections of sewer and altimetry,

- determine the scope and objective,

- cleaning of controlled sewers,

- limit the flow of wastewater to vehicle cameras can pass smoothly (in other flow diversion ditches, temporary increase the level of wastewater in system, water pumping),

- ventilation of controlled sewers and detection of air quality in the sewers to prevent of explosion and control of maximum gas concentrations,

- installation of necessary traffic signs, which was approved by the transport authorities,

- select appropriate camera type, traction, intensity and drive speed cameras. Travel speed is no higher than $15 \mathrm{~cm} / \mathrm{s}$.

- measure the depth of manholes, sewers dimension and identification of the type of building materials sewers.

Sewer network operator's own inspection system and operates it. The inspection system includes a television camera with various accessories (wheels of different sizes, trucks and preparations other than circular profile, devices for measuring inclinations pipes, equipment for measuring the dimensions of findings), jumper cables, a control unit for controlling the camera monitor to observe 
the inspection, recording equipment for making video or still images, computer, printer and related software equipment.

In Figure 3, there is clearly visible corrosion damage to the inner surface of the input shaft. It is seen already aggregates used in the manufacture of concrete rings that make up the chimney inlet manholes. Because the aggregates are visible, it can be assumed that the initial thickness of $10 \mathrm{~cm}$ concrete of concrete ring current disruption exceeds $3 \mathrm{~cm}$, so the chimney shaft is weakened by about $1 / 3$ of its thickness.

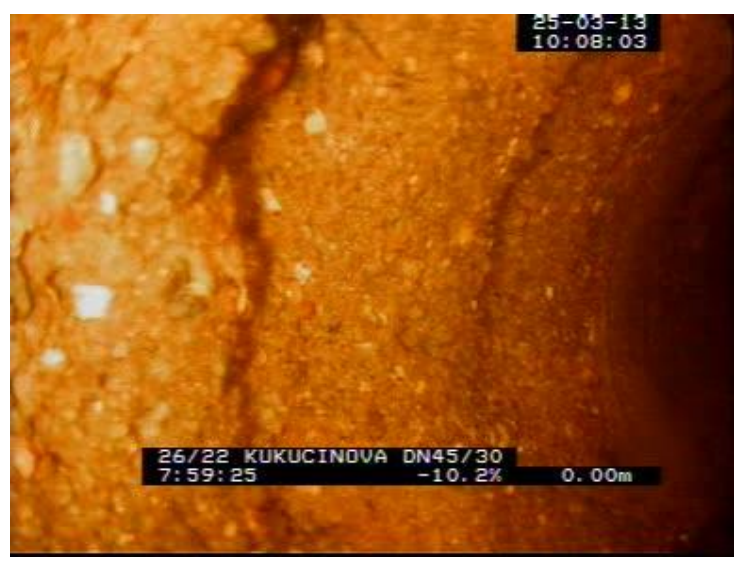

Fig. 3 Sewer pipe deteriorated by suplhate corrosion caused by microorganisms

The image made from video surveillance monitoring is shown in Figure 4. It was carried out by operators of the study sewer system. Disruption of transverse crack including starting disruption of the internal surface of the sewer (DN 600 , thickness $80 \mathrm{~mm}$ ) $\mathrm{mm}$ is visible.

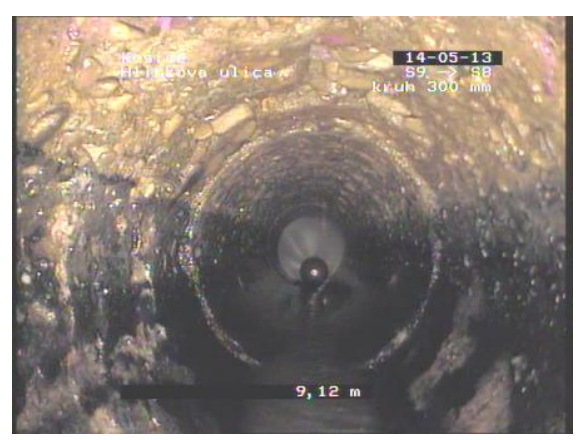

Fig. 4 Sewer pipe deteriorated by suplhate corrosion - cement matrix is disrupted 
Results from the operator's records of disruption of examined sewer network for a year 2012 are shown in Figure 5.

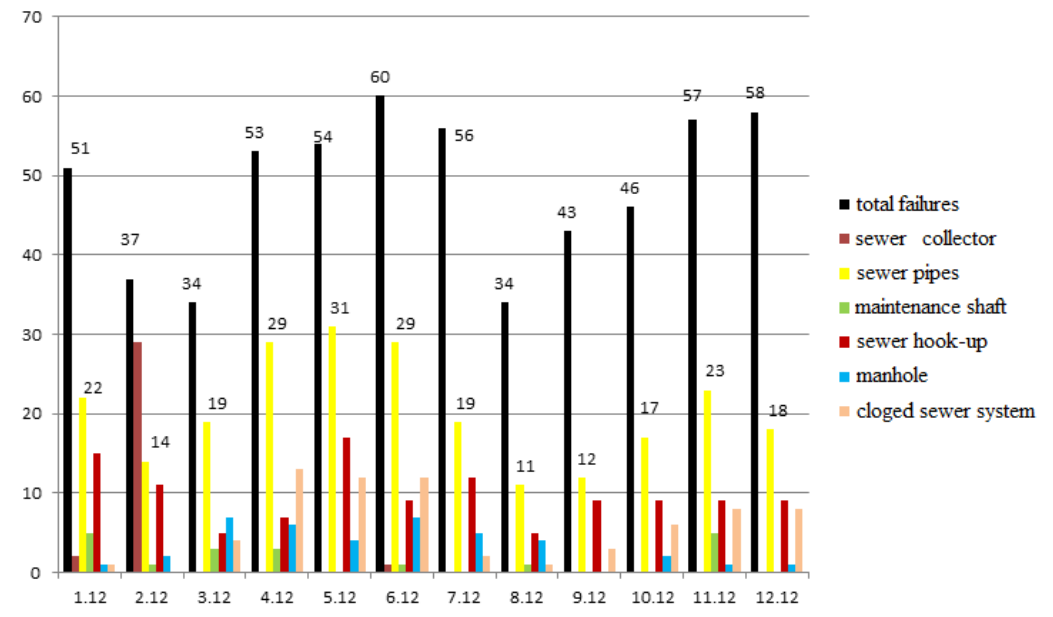

Fig. 5 Records and types of failures in examined sewer system in Kosice city (year 2012)

As it seen in the Fig. 5, the majority of reported failures is at the street sewers, while the failures at the sewers collectors is detected only by camera monitoring of operator of Kosice sewer system.

Except these information also the weight changes can be useful for demage of sewer material determination. Usually it correspondes with the results of compression strenght and leaching of the chemical compounds from the concrete matrix.

\subsubsection{Weight changes}

The weight changes can be determined by gravimetric method measured by analytical balance within $0.00001 \mathrm{~g}$. The increase of weight by $1.81 \%$ was determined in case of samples immersed into the wastewater for 6 months. That may be caused by precipitation of new crystal products on the samples surface and start of forming the new products in the concrete matrix. In the samples exposed to the aggressive environment for longer time, the process of compounds leaching from cement matrix likely override up the process of surface precipitation and thus the weight loss starts. The average weight of samples exposed to wastewater for 12 month, decreased slightly by $0.65 \%$ and for samples exposed for 18 month much higher decrease of concrete samples weight was observed $(1.7 \%)$ [14]. 


\section{Conclusion}

The choice of testing methods is depending on various parameters such as the scale of test method, physical state of attacking medium, $\mathrm{pH}$ and concentration of solution, mechanical action, pressure, size of sample, type of environment, chemical and microbiological composition of wastewater, time of exposition to aggressive media, etc. Sample preparation procedure and the concrete age at the time of testing are of the utmost importance. Regarding relative performance of concrete types a different conclusion may be formulated. Often a combination of multiple relevant indicators will be necessary. The research in field of the biocorrosion of sewer pipes materials should result in development of the standardized method for the deterioration process identification.

\section{Acknowledgement}

This work was financially supported by Slovak Grant Agency for Science within the Grant No. 2/0166/11 and 1/0481/13.

\section{References}

[1] Okabe S. et al.: Succesion of sulphur oxidizing bacteria in microbial community on corroding concrete in sewer system, Applied and Environmental Microbilogy, vol. 73, no.3, 2007, p. 971-980.

[2] L.C. Xu et al.: Application of atomic force microscopy in the study of microbiologically influenced corrosion, Materials Characterisation, vol. 5476, 2002, p. 1-9.

[3] De Belie, N.: Evaluation of methods for testing concrete degradation in aggressive solutions, In N. De Belie (Ed.), Workshop on Performance of Cement-based Materials in Aggressive Aqueous Environments - Characterisation, Modelling, Test Methods and Engineering Aspects, 2007, p. 79-90.

[4] De Belie, N. et al.: Experimental research and modelling of the effect of chemical and biogenic sulphuric acid on different types of commercially produced concrete sewer pipes, Cement and Concrete Rsearch,vol. 34, 2004, p. 2223-2236.

[5] Bertron A. et al.: Cement paste alteration by liquid manure organic acids: chemical and mineralogical characterization, Cement and Concrete Research, vol. 34, 2004, p.1823-1835.

[6] Monteny et al., Chemical, microbiological, and in situ test methods for biogenic sulfuric acid corrosion of concrete, Cement and Concrete Research, vol. 30, no.1, 2000, p.623-634.

[7] Maltais Y. et al: Predicting the durability of Portland cement systems in aggressive environments - Laboratory validation, Cement and Concrete Research, vol. 34, no. 9, 2004, p.1579-1589.

[8] Rogers R. D. et al.: Development of test methods for assessing microbial influenced degradation of cement-solidified radioactive and industrial waste, Cement and Concrete Research, vol. 33, 2003, p.2069-2076. 
[9] Ratneshwar L. et al.: Biological applications of atomic force microscopy, American Journal of Physiology: Cell Physiology, vol. 266, 1994, p. C1-C21.

[10] Altshuler A.T.: Examination of plain carbon steels using an atomic force microscope, SC Cohen, MT Bray, ML Lightbody (Eds.), Atomic force microscopy/scanning tunneling microscopy, Plenum, New York (1994), p. 167-180

[11] IB Beech I.B. et al.: Comparative studies of bacterial biofilms on steel surfaces using atomic force microscopy and environmental scanning electron microscopy, Biofouling, vol. 10, 1996, p. 65-77.

[12] Mansfield F. et al.: A technical review of electrochemical techniques applied to microbiologically influenced corrosion, Corrosion Science, vol. 32, 1991, p. 247272.

[13] Dexter S. C. et al.: Use and limitation of electrochemical techniques for investigating microbiological corrosion, Corrosion, vol. 47, 1991, p. 308-317.

[14] Ondrejka Harbulakova et al.: Study of concrete changes characteristics after biocorrosion proccesses affected by wastewater, Zeszyty Naukowe Politechniki Rzeszowskiej: Budownictwo i Inżynieria Środowiska, vol. 59, no. 2, 2012, p. 13-21.

[15] Ondrejka Harbulakova et al.: Deterioration of concrete composites placed in several pipelines evaluated by calcium and silicon ions changes, SGEM 2013: 13th International Multidisciplinary Scientific Geoconference: Ecology, Economics, Education and Legislation: conference proceedings, vol.1, 2013, p. 16-22

[16] Ondrejka Harbulakova et al.: Pôsobenie vybraných druhov baktérií na trvanlivost' stavebných materiálov v životnom prostredí, Ecological and tourist advantages of the north part of Carpathian euroregion, Brzozów: Muzeum Regionalne, 2010, p. 363 371. /in Slovak/.

[17] Ondrejka Harbulakova et al.: Možnosti minimalizácie vplyvu mikrobiálnej korózie betónových materiálov, CHISA 2009, Praha: ČSCHI, 2009, p. 1-6. /in Slovak/.

[18] Ondrejka Harbulakova et al:: Biodeteriorizácia betónových konštrukcií ako dôsledok pôsobenia vybraných druhov baktérií nachádzajúcich sa v kyslých, Acta Universitatis Prešoviensis: Folia Oecologica, vol. 3, no. 51, 2010, s. 28-34. /in Slovak/

[19] Hyánek L., Rešetka D., Koller J., Nesměrák I.: Čistota vôd, ALFA, Bratislava 1991.

\section{METHODS FOR EVALUATION OF SEWER PIPES MATERIAL DETERIORATION}

\section{S u m m a r y}

It is very important to review and define appropriate test methods to asses performance of cement - based materials in environments of sewer system and which can be used to characterize and rate relative performance, as well as to inform long term prediction. The choice of testing methods is depending on various parameters such as the scale of test method, physical state of attacking medium, $\mathrm{pH}$ and concentration of solution, mechanical action, pressure, size of sample, type of environment, time of exposition to aggressive media, etc. Sample preparation procedure and the concrete age at the time of testing are of the utmost importance. Regarding relative performance of concrete types a different conclusion may be formulated. The paper is aimed at the 
presentation of the selected methods used for testing the concrete composites for the resistance against sulphate attack.

Keywords: sewer pipes, deterioration, investigation of corrosion, concrete

DOI:10.7862/rb.2014.57

Przesłano do redakcji: lipiec $2014 \mathrm{r}$.

Przyjęto do druku: wrzesień $2014 r$. 